\title{
PENGARUH KEPEMILIKAN MANAJERIAL, KEPEMILIKAN INSTITUSIONAL,PERTUMBUHAN PENJUALAN DAN UKURAN PERUSAHAAN TERHADAP KEBIJAKAN UTANG
}

(Studi Pada Perusahan Sub Sektor Otomotif dan Komponen yang Terdaftar di Bursa Efek Indonesia Periode 2013-2017)

\author{
Ade Imam Muslim \\ imemmuslim81@gmail.com \\ Irna Fitria Puspa \\ irnafitriapuspa08@gmail.com
}

Ekuitas School of Business

\begin{abstract}
This research aiming to know influence managerial ownership, institutional ownership, sales growth and size to debt policy. Independent variable in this research is managerial ownership, institutional ownership, sales growth and size, while dependent variable in this research is debt policy. This research using descriptive and verification method. Population in this research is company sub sector automotive and component has registered in Bursa Efek Indonesia period 2013 until 2017. Sample in this research determined using purposive sampling technique. From 13 company, has been obtained 8 company has fulfilling criteria for became research sample. The research result showing a partial managerial ownership has positive effect to debt policy, institutional ownership has no take effect to debt policy, sales growth has negative effect to debt policy and size has no take effect to debt policy. Other than that, in a manner simultaneous managerial ownership, institutional ownership, sales growth and size have taken effect to debt policy by $95,13 \%$.
\end{abstract}

Keyword: Debt Policy, Managerial Ownership, Institutional Ownership, Sales Growth,

\section{Pendahuluan}

Menurut Sudana (2011:7) tujuan perusahaan adalah memaksimalkan kemakmuran pemegang saham. Dalam mewujudkan tujuan tersebut, pemilik modal memberikan wewenang kepada manajer untuk mengambil keputusan, salah satunya mengenai keputusan pendanaan. Menurut Musthafa (2017:6) keputusan pendanaan (financing decision) adalah keputusan untuk memilih kebijakan jenis dana yang akan digunakan dalam kegiatan operasi perusahaan, apakah dari modal sendiri atau diperoleh dari luar perusahaan secara kredit atau pinjaman. Menurut Mulyati (2016) kebijakan utang adalah kebijakan yang diambil oleh pihak manajemen dalam rangka memperoleh sumber pembiayaan bagi perusahaan sehingga dapat digunakan untuk membiayai aktivitas operasional perusahaan.

Terdapat resiko dari penggunaan utang dalam struktur modal perusahaan. Penggunaan utang dalam jumlah yang besar akan meningkatkan risiko perusahaan, yang meningkatkan biaya dari utang. Jika perusahaan mengalami masa-masa yang buruk dan laba operasinya tidak mencukupi untuk menutup beban bunga, pemegang saham terpaksa harus menutupi kekurangan tersebut; jika tidak bisa, perusahaan tersebut akan bangkrut (Bringham dan Houston, 2011). 
Fenomena perusahaan yang mengalami kebangkrutan karena kebijakan utang terjadi pada beberapa perusahaan manufaktur di Indonesia. Sepanjang tahun 2017, dua perusahaan manufaktur dinyatakan pailit oleh Pengadilan Niaga Jakarta karena tidak mampu membayar bunga dan pokok utang kepada kreditur. Perusahaan yang dinyatakan pailit tersebut adalah PT Asia Paper Mills (APM) dengan total utang sebesar Rp 520,17 miliar dan PT Dwi Aneka Jaya Kemasindo Tbk (DAJK) dengan total utang sebesar Rp1,05 triliun (www.kontan.co.id, diunduh 24 September 2018). Kasus kepailitan yang dialami oleh PT Asia Paper Mills (APM) dan PT Dwi Aneka Jaya Kemasindo Tbk (DAJK) menjadi pesan penting bagi pihak manajemen untuk mempertimbangkan komposisi penggunaan utang dalam struktur modal perusahaan, serta mengelola utang secara lebih baik lagi.

Terdapat beberapa faktor yang diduga berpengaruh terhadap kebijakan utang diantaranya adalah kepemilikan manajerial, kepemilikan institusional, pertumbuhan penjualan dan ukuran perusahan. Kebijakan utang diproksikan oleh Debt to Equity Ratio (DER), rasio ini membandingkan total utang dengan ekuitas perusahaan. Semakin rendah
DER mengindikasikan kemampuan perusahaan menyelesaikan kewajibannya melalui ekuitas semakin baik.

Berdasarkan teori sinyal, perusahaan yang mampu menghasilkan laba cenderung meningkatkan jumlah utangnya, karena tambahan pembayaran bunga akan diimbangi dengan laba sebelum pajak (Sudana, 2011:156). Sinyal merupakan suatu tindakan yang diambil oleh manajemen suatu perusahaan untuk memberikan petunjuk kepada investor tentang bagaimana manajemen menilai prospek perusahaan tersebut. Perusahaan dengan prospek yang sangat menguntungkan akan menghindari penjualan saham, dan sebagai gantinya, menghimpun modal baru menggunakan utang (Brigham dan Houston, 2011:185). Namun teori tersebut tidak sejalan dengan fakta yang ditemukan pada salah satu perusahaan sub sektor otomotif dan komponen periode 2013-2017 yaitu PT Selamat Sempurna Tbk (SMSM).

Berikut ini adalah data perkembangan kepemilikan manajerial, kepemilikan institusional, pertumbuhan penjualan, ukuran perusahaan dan kebijakan utang pada PT Selamat Sempurna Tbk (SMSM) periode 20132017.

Tabel 1 : Perkembangan Kepemilikan Manajerial, Kepemilikan Institusional, Pertumbuhan Penjualan, Ukuran Perusahaan dan Kebijakan Utang(DER) pada PT Selamat Sempurna Tbk (SMSM) periode 2013-2017.

\begin{tabular}{|c|c|c|c|c|c|}
\hline Tahun & $\begin{array}{c}\text { Kepemilikan } \\
\text { Manajerial } \\
(\%)\end{array}$ & $\begin{array}{c}\text { Kepemilikan } \\
\text { Institusional } \\
(\%)\end{array}$ & $\begin{array}{c}\text { Pertumbuhan } \\
\text { Penjualan } \\
(\%)\end{array}$ & $\begin{array}{c}\text { Ukuran } \\
\text { Perusahaan }\end{array}$ & DER \\
\hline 2013 & 8,34 & 58,13 & 9,67 & 28,16 & 0,69 \\
\hline 2014 & 8,34 & 58,13 & 10,95 & 28,19 & 0,53 \\
\hline 2015 & 8,00 & 58,13 & 6,46 & 28,43 & 0,54 \\
\hline 2016 & 8,00 & 58,13 & 2,75 & 28,44 & 0,43 \\
\hline 2017 & 8,00 & 58,13 & 15,97 & 28,52 & 0,34 \\
\hline
\end{tabular}

Sumber : Data diolah Peneliti, 2018 
Berdasarkan tabel 1, dapat diketahui bahwa utang pada PT Selamat Sempurna Tbk (SMSM) memiliki rasio yang rendah dan cenderung menurun selama 5 tahun. Pertumbuhan penjualan pada perusahan tersebut mengalami peningkatan setiap tahunnya. Artinya, laba perusahaan pun akan meningkat. Kepemilikan manajerial dan institusional pada perusahaan tersebut termasuk dalam kategori yang tinggi. Adanya kepemilikan manajerial dan kepemilikan institusional dalam perusahaan dipercaya memiliki kemampuan untuk mempengaruhi jalannya perusahaan yang nantinya dapat mempengaruhi kinerja suatu perusahaan (Subagyo dkk., 2017:46). Perusahaan yang memiliki aset yang banyak artinya perusahaan memiliki prospek yang baik. Fakta yang terjadi pada PT Selamat Sempurna Tbk (SMSM) tidak sesuai dengan teori sinyal namun justru berbanding terbalik.

Motivisi dari penelitian ini terutama didorong oleh keinginan untuk menganalisis kebijakan utang beserta faktor-faktor yang mempengaruhinya. Menurut pengetahuan peneliti, penelitian terkait faktor-faktor yang mempengaruhi kebijakan utang telah banyak dilakukan, Astuti (2014), Hasan (2014), namun khusus untuk sektor otomotif masih belum banyak dilakukan, sehingga menjadi peluang peneliti untuk melakukan penelitian lebih lanjut.

Urgensi dari penelitian ini terutama dapat memberikan gambaran kebijakan utang, baik secara khusus untuk sektor otomotif, maupun untuk sektor lainnya beserta faktor-faktor yang mempengaruhinya. Lebih jauh dapat menjadi rujukan bagi regulator dalam memberikan regulasi terkait kebijakan utang sektor otomotif.

\section{KERANGKA TEORITIS DAN HIPOTESIS}

\section{A. Kerangka Teoritis}

Penelitian ini dapat dijelaskan melalui teori sinyal, teori trade off, teori pecking order dan teori agensi. Berdasarkan signaling theory (teori sinyal), perusahaan yang mampu menghasilkan laba cenderung meningkatkan jumlah utangnya, karena tambahan pembayaran bunga akan diimbangi dengan laba sebelum pajak (Sudana, 2011:156). Berdasarkan Teori Trade-off $t$ keputusan perusahaan menggunakan utang didasarkan pada keseimbangan antara penghematan pajak dan kesulitan keuangan suatu perusahaan (Sudana, 2011:153). Menurut Siregar (2005) dalam Steven dan Lina (2011) utang menyebabkan perusahaan memperoleh manfaat pajak karena biaya bunga dapat dibebankan dari penghasilan kena pajak, sedangkan biaya kebangkrutan merupakan biaya administrasi, biaya hukum, biaya keagenan, dan biaya monitoring untuk mencegah perusahaan dari kebangkrutan. Pecking order theory secara tidak langsung menyatakan manajer perusahaan sebaiknya menerbitkan surat utang lebih dahulu sebelum menerbitkan surat utang yang bisa dikonversikan. Perusahaan menerbitkan surat utang yang lebih aman. Pecking order theory menjelaskan setiap perusahaan memilih rasio penggunaan utang berdasarkan atas keputusan pendanaan. Hal ini akan menurunkan persentase penggunaan utang dalam struktur modal perusahaan karena perusahaan mampu menghasilkan laba. Perusahaan yang menguntungkan akan menghasilkan kas dari dalam perusahaan, sehingga megurangi kebutuhan pendanaan yang berasal dari luar perusahaan (Sudana, 2015:174). 
Dalam teori agensi (agency theory) hubungan antara manajer dan pemegang saham digambarkan sebagai hubungan antara agent dan principal. Pemegang saham dan manajer masing-masing memiliki kepentingan untuk memaksimalkan tujuannya. Konflik kepentingan terjadi jika keputusan manajer hanya memaksimalkan kepentingannya dan tidak sejalan dengan kepentingan pemegang saham (Brigham dan Houston, 2009:27). Agency problem akan terjadi bila proporsi kepemilikan manajer atas saham kurang dari 100\%. sehingga manajer cenderung bertindak untuk mengejar kepentingannya dirinya dan sudah tidak berdasarkan memaksimalkan nilai perusahaan dalam pengambilan keputusan keuangan khususnya keputusan pendanaan. Kondisi tersebut merupakan konsekuensi dari fungsi pengelola dengan fungsi kepemilikan, manajemen tidak menanggung resiko atas kesalahan dalam mengambil keputusan, resiko tersebut sepenuhnya ditanggung pemegang saham (prinsipal). Oleh karena itu, manajemen cenderung melakukan pengeluaran yang bersifat konsumtif dan tidak produktif untuk kepentingan pribadinya (Jensen dan Meckling dalam Indahningrum dan Handayani, 2009).

\section{Kebijakan Utang}

Menurut Mulyati (2016) kebijakan utang adalah kebijakan yang diambil oleh pihak manajemen dalam rangka memperoleh sumber pembiayaan bagi perusahaan sehingga dapat digunakan untuk membiayai aktivitas operasional perusahaan. Kebijakan utang diproksikan oleh Debt to Equity Ratio. Menurut Harahap (2015:303) rasio ini menggambarkan sampai sejauh mana modal pemilik dapat menutupi utangutang kepada pihak luar. Semakin kecil rasio ini semakin baik. Perusahaan yang baik mestinya memilki komposisi modal yang lebih besar dari utang. DER diformulasikan sebagai berikut (Kasmir, 2013:158).

\section{$D E R=\frac{\text { Total Utang }}{\text { Total Ekuitas }}$}

\section{Kepemilikan Manajerial}

Menurut Subagyo, dkk. (2017:46) kepemilikan manajerial adalah kepemilikan saham oleh manajemen perusahaan yang diukur dengan persentase jumlah saham yang dimiliki manajemen. Kepemilikan manajerial di formulasikan sebagai berikut (Jensen dan Meckling dalam Hasan, 2014).

\section{KM $=\frac{\text { Jumlah Saham Komisaris, direksi }}{\text { Total } \text { Saham Beredar }}$}

\subsubsection{Kepemilikan Institusional}

Menurut Subagyo, dkk. (2017:46) kepemilikan institusional adalah kepemilikan saham oleh pemerintah, institusi keuangan, institusi berbadan hukum, institusi luar negeri, dana perwalian, dan institusi lainnya pada akhir tahun. Kepemilikan institusional diformulasikan sebagai berikut (Masdupi dalam indahningrum dan Handayani, 2009).

$$
K I=\frac{\text { Jumlah Saham Institusi }}{\text { Total Saham Beredar }}
$$

\section{Pertumbuhan Penjualan}

Menurut Brigham dan Houston dalam Soukotta (2012) pertumbuhan penjualan adalah perubahan (peningkatan atau penurunan) total penjualan yang dimiliki perusahaan. Pertumbuhan penjualan merupakan perbandingan 
antara perubahan penjualan tahun sekarang dan tahun lalu terhadap penjualan tahun lalu. Pertumbuhan penjualan atau sales growth diformulasikan sebagai berikut (Harahap , 2015:309).

Sales Growth $=\frac{\text { Salest }- \text { Salest-1 }}{\text { Salest-1 }}$

\section{Ukuran Perusahaan}

Menurut Hery (2017:11) ukuran perusahaan adalah suatu skala dimana dapat diklasifikasikan besar kecil perusahaan menurut berbagai cara antara lain dengan total aset, nilai pasar saham, dan lain-lain. Ukuran perusahaan diformulasikan sebagai berikut (Steven dan Lina, 2011).

$$
\text { Size }=\operatorname{Ln}(\text { Total asset })
$$

\section{B. Hipotesis}

\section{Pengaruh Kepemilikan Manajerial} terhadap Kebijakan Utang

Dengan adanya kepemilikan manjerial yang tinggi manajer cenderung menggunakan utang untuk membiayai kebutuhan keuangan perusahaan. Hal ini dapat dijelaskan melalui trade off antara konflik keagenan utang dengan konflik keagenan ekuitas. Perusahaan dengan kepemilikan manajerial memiliki konflik keagenan ekuitas yang rendah sehingga kecenderungan menggunakan utang sehingga meningkatkan konflik keagenan utang. Manajer cenderung menggunakan utang untuk membiayai investasi. Penggunaan sumber pendanaan dari luar (utang) lebih banyak menunjukkan signal bahwa perusahaan memiliki prospek yang baik. Hal ini mengindikasikan bahwa kinerja manajer cukup baik, karena adanya kepercayaan dari debtholders. Keputusan manajer dapat berupa signal bahwa perusahaan berkinerja baik yaitu ketika perusahaan memutuskan menggunakan dana eksternal, karena hanya perusahaan dengan pendapatan relatif stabil yang berani menambah utangnya (Kahar,2008). Menurut Haruman (2008) semakin besar proporsi kepemilikan saham oleh manajerial maka akan meningkatkan utang perusahaan. Hal ini menunjukkan bahwa kepemilikan manajerial lebih memilih sumber pembiayaan yang paling mudah yaitu dengan menggunakan utang, dibandingkan dengan menerbitkan saham.

Hasil penelitian yang dilakukan oleh Kahar (2008), Haruman (2008), menunjukkan bahwa kepemilikan manajerial berpengaruh secara positif terhadap kebijakan utang. Sedangkan hasil penelitian yang dilakukan Indahningrum dan Handayani (2009), Larasati (2011), Steven dan Lina (2011) menunjukkan bahwa kepemilikan manajerial tidak berpengaruh terhadap kebijakan utang.

\section{$\mathrm{H}_{1}$ :Kepemilikan manajerial berpengaruh terhadap kebijakan utang.}

\section{Pengaruh Kepemilikan Institusional terhadap Kebijakan Utang}

Menurut Indahningrum dan Handayani (2009) kepemilikan institusional memiliki pengaruh searah dengan prediksi kebijakan utang perusahaan. Semakin tinggi kepemilikan institusional, maka akan semakin tinggi kebijakan utang perusahaan. Kepemilikan institusional yang lebih besar bila dibandingkan dengan pemegang saham kelompok lain dalam suatu perusahaan membuat kepemilikan intitusional memiliki wewenang yang besar. Adanya kecenderungan kepemilikan institusional untuk memilih proyek 
yang lebih beresiko dengan harapan akan memperoleh keuntungan yang tinggi. Untuk membiayai proyek tersebut, investor memilih pembiayaan melalui utang. Dengan kebijakan tersebut, mereka dapat mengalihkan penangguhan resiko kepada pihak kreditor apabila proyek gagal. Bila proyek berhasil, pemegang saham akan mendapat hasil sisa karena kreditor hanya akan dibayar sebesar tertentu yaitu berupa bunga.

Hasil penelitian yang dilakukan oleh Indahningrum dan Handayani (2009), Larasati (2011), Nuraina (2012) menunjukkan bahwa kepemilikan institusional berpengaruh positif terhadap kebijakan utang. Sedangkan hasil penelitian yang dilakukan oleh Haruman (2008), Asuti (2014), Purwasih dkk. (2014) dan Golmohamadi et all. (2015) menunjukkan bahwa kepemilikan institusional tidak berpengaruh terhadap kebijakan utang.

\section{$\mathrm{H}_{2}$ :Kepemilikan institusional berpengaruh terhadap kebijakan utang.}

\section{Pengaruh Pertumbuhan Penjualan terhadap Kebijakan Utang}

Menurut Brigham dan Houston (2011:321), semakin tinggi tingkat pertumbuhan penjualan, suatu perusahaan akan lebih banyak mengandalkan modal eksternal. Perusahaan yang tingkat pertumbuhan penjualannya relatif tinggi dimungkinkan untuk dibelanjai dengan menggunakan utang lebih besar dibandingkan dengan perusahaan yang pertumbuhan penjualannya rendah, karena keuntungan yang diperoleh dari peningkatan penjualan tersebut diharapkan masih bisa menutup biaya bunga utang. Perusahaan yang penjualannya relatif stabil dari waktu ke waktu dimungkinkan untuk dibelanjai dengan utang yang lebih banyak dibandingkan dengan perusahaan yang penjualannya sangat berfluktuasi atau bersifat musiman, karena jika menggunakan utang dalam jumlah yang besar dengan beban bunga yang tetap, perusahaan yang penjualannya bersifat musiman dapat menghadapi kesulitan keuangan ketika sedang tidak musimnya atau saat penjualan mengalami penurunan (Sudana, 2011:162).

Hasil penelitian yang dilakukan oleh Hidayat (2013), Mulyati (2016), menunjukkan bahwa pertumbuhan penjualan berpengaruh positif terhadap kebijakan utang. Sedangkan, hasil penelitian yang dilakukan oleh Bayunitri dan Malik (2015) menunjukkan bahwa pertumbuhan penjualan berpengaruh negatif terhadap kebijakan utang.

$\mathrm{H}_{3}=$ Pertumbuhan penjualan berpengaruh terhadap kebijakan utang.

\section{Pengaruh Ukuran Perusahaan terhadap Kebijakan Utang}

Menurut Prasetyorini dalam Hery (2017:11), semakin besar ukuran atau skala perusahaan maka akan semakin mudah bagi perusahaan dalam memperoleh sumber pendanaan, baik bersifat internal maupun eksternal. Menurut Steven dan Lina (2011) perusahaan yang besar dapat dengan mudah mengakses pasar modal. Karena kemudahan tersebut perusahan memiliki fleksibilitas dan kemampuan untuk mendapatkan dana baik melalui saham maupun utang. Perusahaan besar akan lebih mudah mendapatkan utang karena perusahaan besar biasanya mempunyai aset yang lebih banyak.

Hasil penelitian yang dilakukan oleh Astuti (2014), Hasan (2014) menunjukkan bahwa ukuran perusahaan berpengaruh positif terhadap kebijakan 
utang. Sedangkan hasil penelitian yang dilakukan oleh Steven dan Lina (2011), Nuraina (2012) menunjukkan bahwa ukuran perusahaan tidak berpengaruh terhadap kebijakan utang.

\section{H4: Ukuran perusahaan berpengaruh terhadap kebijakan utang}

\section{METODOLOGI}

\section{A. Metode Penelitian}

Metode penelitian yang digunakan adalah metode deksriptif dan verifikatif. Menurut Sugiyono (2014:147) metode dekstiptif merupakan suatu metode yang digunakan untuk menganalisis data dengan cara mendeksripsikan atau menggambarkan data yang telah terkumpul sebagaimana adanya tanpa maksud membuat kesimpulan yang berlaku untuk umum atau generalisasi. Sedangkan metode verifikatif adalah metode penelitian yang bertujuan untuk mengetahui hubungan antara dua variabel atau lebih. Penelitian verifikatif bertujuan untuk memverifikasi kebenaran hasil penelitian sebelumnya.

\section{B. Populasi dan sampel}

Populasi dalam penelitian ini adalah perusahaan sub sektor otomotif dan komponen yang terdaftar di Bursa Efek Indonesia periode 2013-2017. Sampel dalam penelitian ini ditentukan dengan menggunakan teknik purposive sampling. Menurut Sugiyono (2014:122) purposive sampling adalah teknik penentuan sampel dengan pertimbangan tertentu. Kriteria penentuan sampel sebagai berikut:

1. Perusahaan manufaktur sub sektor otomotif dan komponen yang terdaftar di Bursa Efek Indonesia periode 2013-2017.

2. Perusahaan manufaktur sub sektor otomotif dan komponen memiliki laporan keuangan lengkap periode 2013-2017.

3. Perusahaan yang menyajikan laporan keuangan dengan IDR.

Tabel 2: Sampel Penelitian

\begin{tabular}{|l|l|l|l|}
\hline No & \multicolumn{1}{|c|}{ Nama Perusahaan } & No & Nama Perusahaan \\
\hline 1 & PT Astra International Tbk & 5 & PT Indospring Tbk \\
\hline 2 & PT Astra Otoparts Tbk & 6 & PT Prima Alloy Steel Universal Tbk \\
\hline 3 & PT Gajah Tunggal Tbk & 7 & PT Selamat Sempurna Tbk \\
\hline 4 & PT Indomobil Sukses International & 8 & PT Nipress Tbk \\
\hline
\end{tabular}

Sumber: www.sahamok.com

\section{Desain Penelitian}

Desain penelitian digambarkan sebagai berikut:

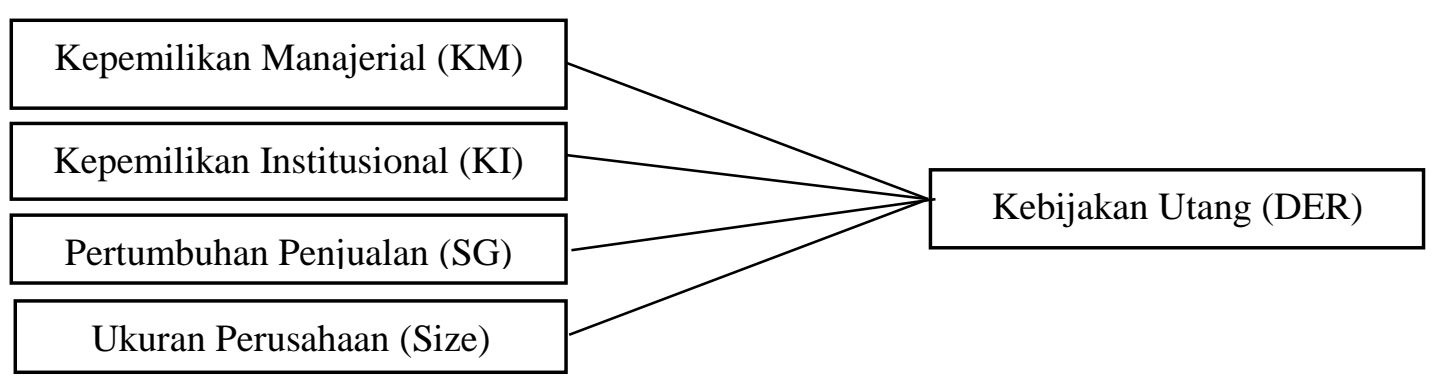

Gambar 1: Desain penelitian 


\section{Metode Analisa Data}

Alat analisis data yang digunakan adalah Eviews 9 (Econometric Views), menggunakan regresi data panel. Menurut Widarjono (2016:353) data panel merupakan gabungan dua data time series (data berkala) dan cross section (data individual). Terknik analisa data yang digunakan adalah teknik regresi linear berganda untuk memprediksi variabel indepanden yaitu kepemilikan manajerial, kepemilikan institusional, pertumbuhan penjualan dan ukuran perusahaan terhadap variabel depanden yaitu kebijakan utang. model persamaan regresi dirumuskan sebagai berikut :

\section{$D E R=\alpha+\beta_{1} K M_{1}+\beta_{2} K I_{2}+\beta_{3} S G_{3}+\beta_{4} L_{o g S i z e}+\varepsilon$}

Keterangan:

DER = Kebijakan Utang

$\mathrm{KM}=$ Kepemilikan Manajerial

KI = Kepemilikan Institusional

SG = Pertumbuhan Penjualan

Size = Ukuran Perusahaan

$\alpha \quad=$ konstanta

$\beta_{1}, \beta_{2}, \beta_{3}, \beta_{4}=$ Koefisien regresi

e $\quad=$ Error term

\section{HASIL PENELITIAN DAN PEMBAHASAN}

A. Statistik Deskriptif

Berikut ini adalah data perkembangan kepemilikan manajerial, kepemilikan institusional, pertumbuhan penjualan dan ukuran perusahaan terhadap kebijakan utang pada perusahan sub sektor otomotif dan komponen yang terdaftar di Bursa Efek Indonesia peride 2013-2017.

Tabel 3 : Kepemilikan Manajerial pada Perusahaan Manufaktur Sub Sektor Otomotif dan Komponen yang terdaftar di BEI Periode 2013-2017

\begin{tabular}{|c|l|c|c|c|c|c|}
\hline No & $\begin{array}{c}\text { Kode } \\
\text { Perusahaan }\end{array}$ & 2013 & 2014 & 2015 & 2016 & 2017 \\
\hline 1 & ASII & $0,04 \%$ & $0,04 \%$ & $0,04 \%$ & $0,04 \%$ & $0,04 \%$ \\
\hline 2 & GJTL & $0,09 \%$ & $0,11 \%$ & $0,94 \%$ & $1,13 \%$ & $1,13 \%$ \\
\hline 3 & INDS & $0,44 \%$ & $0,44 \%$ & $0,44 \%$ & $0,44 \%$ & $0,44 \%$ \\
\hline 4 & NIPS & $12,40 \%$ & $6,01 \%$ & $6,01 \%$ & $8,39 \%$ & $8,39 \%$ \\
\hline 5 & PRAS & $4,96 \%$ & $4,96 \%$ & $4,96 \%$ & $4,96 \%$ & $4,96 \%$ \\
\hline 6 & SMSM & $8,34 \%$ & $8,34 \%$ & $8,00 \%$ & $8,00 \%$ & $8,00 \%$ \\
\hline 7 & AUTO & $0,06 \%$ & $0,02 \%$ & $0 \%$ & $0 \%$ & $0 \%$ \\
\hline 8 & IMAS & $0 \%$ & $0 \%$ & $0 \%$ & $0 \%$ & $0 \%$ \\
\hline \multicolumn{2}{|c|}{ Maksimum } & $12,40 \%$ & $8,34 \%$ & $8,00 \%$ & $8,39 \%$ & $8,39 \%$ \\
\hline \multicolumn{2}{|c|}{ Minimum } & $0 \%$ & $0 \%$ & $0 \%$ & $0 \%$ & $0 \%$ \\
\hline \multicolumn{2}{|c|}{ Rata- Rata } & $3,29 \%$ & $2,49 \%$ & $2,55 \%$ & $2,87 \%$ & $2,87 \%$ \\
\hline
\end{tabular}

Sumber: Data diolah

Berdasarkan tabel 3 dapat diketahui bahwa kepemilikan manajerial pada perusahaan sub sektor otomotif dan komponen yang terdaftar di Bursa Efek Indonesia periode 2013-2017 berfluktusi dengan persentase kepemilikan manajerial maksimum sebesar $12,40 \%$ dimiliki oleh NIPS sedangkan persentase kepemilikan manajerial minimum sebesar $0 \%$ dimiliki oleh IMAS dan AUTO. 
Tabel 4 : Kepemilikan Institusional pada Perusahaan Manufaktur Sub Sektor Otomotif dan Komponen yang Terdaftar di BEI Periode 2013-2017

\begin{tabular}{|c|c|c|c|c|c|c|}
\hline No & $\begin{array}{c}\text { Kode } \\
\text { Perusahaan }\end{array}$ & 2013 & 2014 & 2015 & 2016 & 2017 \\
\hline 1 & ASII & $50,11 \%$ & $50,11 \%$ & $50,11 \%$ & $50,11 \%$ & $50,11 \%$ \\
\hline 2 & GJTL & $59,81 \%$ & $59,61 \%$ & $59,62 \%$ & $59,62 \%$ & $59,62 \%$ \\
\hline 3 & INDS & $88,11 \%$ & $88,11 \%$ & $88,11 \%$ & $88,11 \%$ & $88,11 \%$ \\
\hline 4 & NIPS & $37,11 \%$ & $62,91 \%$ & $62,91 \%$ & $59,59 \%$ & $50,37 \%$ \\
\hline 5 & PRAS & $54,07 \%$ & $54,07 \%$ & $54,07 \%$ & $54,07 \%$ & $54,07 \%$ \\
\hline 6 & SMSM & $58,13 \%$ & $58,13 \%$ & $58,13 \%$ & $58,13 \%$ & $58,13 \%$ \\
\hline 7 & AUTO & $80,00 \%$ & $80,00 \%$ & $80,00 \%$ & $80,00 \%$ & $80,00 \%$ \\
\hline 8 & IMAS & $89,54 \%$ & $89,54 \%$ & $89,66 \%$ & $89,66 \%$ & $89,66 \%$ \\
\hline \multicolumn{2}{|c|}{ Maksimal } & $89,54 \%$ & $89,54 \%$ & $89,66 \%$ & $89,66 \%$ & $89,66 \%$ \\
\hline \multicolumn{2}{|c|}{ Minimal } & $37,11 \%$ & $50,11 \%$ & $50,11 \%$ & $50,11 \%$ & $50,11 \%$ \\
\hline \multicolumn{2}{|c|}{ Rata-Rata } & $64,61 \%$ & $67,81 \%$ & $67,83 \%$ & $67,41 \%$ & $66,26 \%$ \\
\hline
\end{tabular}

Sumber: Data diolah peneliti

Berdasarkan tabel 4 dapat diketahui bahwa kepemilikan institusional pada perusahaan sub sektor otomotif dan komponen yang terdaftar di Bursa Efek Indonesia periode 2013-2017 berfluktusi dengan persentase kepemilikan institusional maksimum sebesar $89,66 \%$ dimiliki IMAS dan minimum sebesar $37,11 \%$ oleh ASII.

Tabel 5: Pertumbuhan Penjualan pada Perusahaan Manufaktur Sub Sektor Otomotif dan Komponen yang Terdaftar di BEI Periode 2013-2017

\begin{tabular}{|c|l|c|c|c|c|c|}
\hline No & Kode Perusahaan & 2013 & 2014 & 2015 & 2016 & 2017 \\
\hline 1 & ASII & $3,10 \%$ & $4,03 \%$ & $-8,68 \%$ & $-1,69 \%$ & $13,79 \%$ \\
\hline 2 & GJTL & $-1,79 \%$ & $5,81 \%$ & $-0,77 \%$ & $5,11 \%$ & $3,77 \%$ \\
\hline 3 & INDS & $15,26 \%$ & $9,66 \%$ & $-11,11 \%$ & $-1,35 \%$ & $20,22 \%$ \\
\hline 4 & NIPS & $29,65 \%$ & $11,50 \%$ & $-2,76 \%$ & $5,24 \%$ & $3,60 \%$ \\
\hline 5 & PRAS & $1,92 \%$ & $40,96 \%$ & $5,38 \%$ & $-21,92 \%$ & $-4,97 \%$ \\
\hline 6 & SMSM & $9,67 \%$ & $10,95 \%$ & $6,46 \%$ & $2,75 \%$ & $15,97 \%$ \\
\hline 7 & AUTO & $29,29 \%$ & $14,52 \%$ & $-4,34 \%$ & $9,24 \%$ & $5,80 \%$ \\
\hline 8 & IMAS & $1,59 \%$ & $-3,17 \%$ & $-6,98 \%$ & $-16,85 \%$ & $2,06 \%$ \\
\hline & Maksimal & $29,65 \%$ & $40,96 \%$ & $6,46 \%$ & $9,24 \%$ & $20,22 \%$ \\
\hline & Minimal & $-1,79 \%$ & $-3,17 \%$ & $-11,11 \%$ & $-21,92 \%$ & $-4,97 \%$ \\
\hline \multicolumn{2}{r}{ Rata-Rata } & $11,09 \%$ & $11,78 \%$ & $-2,85 \%$ & $-2,43 \%$ & $7,13 \%$ \\
\hline
\end{tabular}

Sumber: Data diolah

Berdasarkan tabel 5 dapat diketahui bahwa pertumbuhan penjualan pada perusahaan sub sektor otomotif dan komponen yang terdaftar di Bursa Efek Indonesia periode 2013-2017 berfluktusi dengan persentase pertumbuhan penjualan maksimum sebesar 40,96\% dimiliki oleh PRAS dan minimum $-21,92 \%$ dimiliki oleh PRAS. 
Pengaruh Kepemilikan... (Ade Imam, Irna)

Tabel 6: Ukuran Perusahaan perusahaan manufaktur sub sektor otomotif dan komponen yang terdaftar di BEI periode 2013-2017

\begin{tabular}{|c|c|c|c|c|c|c|}
\hline No & Kode Perusahaan & 2013 & 2014 & 2015 & 2016 & 2017 \\
\hline 1 & ASII & 33,00 & 33,10 & 33,13 & 33,20 & 33,32 \\
\hline 2 & GJTL & 30,36 & 30,41 & 30,49 & 30,56 & 30,53 \\
\hline 3 & INDS & 28,42 & 28,46 & 28,57 & 28,54 & 28,52 \\
\hline 4 & NIPS & 27,41 & 27,82 & 28,07 & 28,21 & 28,27 \\
\hline 5 & PRAS & 27,40 & 27,88 & 28,06 & 28,10 & 28,06 \\
\hline 6 & SMSM & 28,16 & 28,19 & 28,43 & 28,44 & 28,52 \\
\hline 7 & AUTO & 30,17 & 30,30 & 30,29 & 30,31 & 30,32 \\
\hline 8 & IMAS & 30,74 & 30,79 & 30,84 & 30,87 & 31,08 \\
\hline \multicolumn{2}{r}{ Maksimal } & 33,00 & 33,10 & 33,13 & 33,20 & 33,32 \\
\hline & Minimal & 27,40 & 27,82 & 28,06 & 28,10 & 28,06 \\
\hline \multicolumn{2}{c}{ Rata-Rata } & 29,46 & 29,62 & 29,74 & 29,78 & 29,83 \\
\hline
\end{tabular}

Sumber: Data diolah

Berdasarkan tabel 6, dapat diketahui bahwa ukuran perusahaan pada perusahaan sub sektor otomotif dan komponen yang terdaftar di Bursa Efek Indonesia periode 2013-2017 berfluktusi dengan ukuran perusahaan maksimum sebesar 33,32 dimiliki oleh ASII dan minimum sebesar 27,40 dimiliki oleh PRAS.

Tabel 7: Kebijakan Utang (DER) pada Perusahaan Manufaktur Sub Sektor Otomotif dan Komponen yang Terdaftar di BEI Periode 2013-2017

\begin{tabular}{|c|c|c|c|c|c|c|}
\hline No & Kode Perusahaan & 2013 & 2014 & 2015 & 2016 & 2017 \\
\hline 1 & ASII & 1,02 & 0,96 & 0,94 & 0,87 & 0,89 \\
\hline 2 & GJTL & 1,68 & 1,68 & 2,25 & 2,20 & 2,20 \\
\hline 3 & INDS & 0,25 & 0,25 & 0,33 & 0,20 & 0,14 \\
\hline 4 & NIPS & 2,38 & 1,10 & 1,54 & 1,11 & 1,16 \\
\hline 5 & PRAS & 0,96 & 0,88 & 1,13 & 1,30 & 1,28 \\
\hline 6 & SMSM & 0,69 & 0,53 & 0,54 & 0,43 & 0,34 \\
\hline 7 & AUTO & 0,32 & 0,42 & 0,41 & 0,39 & 0,37 \\
\hline 8 & IMAS & 2,35 & 2,49 & 2,71 & 2,82 & 2,38 \\
\hline & Maksimal & 2,38 & 2,49 & 2,71 & 2,82 & 2,38 \\
\hline \multicolumn{2}{r}{ Minimal } & 0,25 & 0,25 & 0,33 & 0,20 & 0,14 \\
\hline \multicolumn{2}{r}{ Rata-Rata } & 1,21 & 1,04 & 1,23 & 1,16 & 1,09 \\
\hline
\end{tabular}

Sumber: Data diolah peneliti, 2018

Berdasarkan tabel 7 dapat diketahui bahwa DER pada perusahaan sub sektor otomotif dan komponen yang terdaftar di Bursa Efek Indonesia periode 2013-
2017 berfluktusi dengan DER maksimum sebesar 2,82 dimiliki IMAS dan DER minimum sebesar 0,14 dimiliki

INDS. 


\section{B. Pemilihan Model Data Panel}

Untuk mengetahui pengaruh kepemilkan manajerial, kepemilikan institusional, pertumbuhan penjualan dan ukuran perusahaan terhadap kebijakan utang, terlebih dahulu dilakukan uji chow dan uji hausman untuk memilih model panel data yang tepat apakah common effect, fixed effect, dan random effect.

\section{Uji Chow}

Menurut Widarjono (2016:362) uji Chow dapat digunakan untuk menentukan teknik dengan model pendekatan Pooled Least Square (PLS) atau Fixed Effect (FE). Dasar pengambilan keputusannya adalah jika $\mathrm{H}_{0}$ diterima, maka model Common Effect dan jika $\mathrm{H}_{0}$ ditolak, maka model Fixed Effect. Hasil dari uji chow sebagai berikut:

Tabel 8 : Uji Chow

\begin{tabular}{cccc}
\hline Effect Test & Statistic & Df & Prob \\
\hline Cross Section F & 92.80 & 7,28 & 0.0000 \\
Cross-section Chi Square & 127.45 & 7 & 0.0000 \\
\hline
\end{tabular}

Sumber : Data diolah

Berdasarkan tabel tersebut dapat diketahui bahwa nilai prob sebesar $0,0000<0,05$. Dengan demikian maka $\mathrm{H}_{0}$ ditolak, sehingga model yang dipilih adalah fixed effect.

\section{Uji Hausman}

Menurut Widarjono (2013:264) uji hausman digunakan untuk memilih apakah menggunakan fixed effect atau random effect. Dasar pengambilan keputusannya adalah Jika $\mathrm{H}_{0}$ diterima, maka model Random Effect dan jika $\mathrm{H}_{0}$ ditolak, maka model Fixed Effect. Hasil dari uji hausman sebagai berikut:

Tabel 9 : Uji Hausman

\begin{tabular}{cccc}
\hline Test Summary & Chi-Sq Statistic & $d f$ & Prob \\
\hline Cross Section Random & 13.730 & 4 & 0.0082 \\
\hline
\end{tabular}

Sumber : Data diolah

Berdasarkan tabel tersebut dapat diketahui bahwa nilai prob sebesar $0,0082<0,05$ maka $\mathrm{H}_{0}$ ditolak, sehingga model yang dipilih adalah fixed effect.

\section{Uji Asumsi Klasik}

Menurut Wahyudi (2016:129) uji asumsi klasik merupakan suatu persyaratan yang harus dipenuhi pada model regresi yang menggunakan metode estimasi Ordinary Least Squares (OLS). Uji asumsi klasik terdiri dari uji normalitas, uji mutikolinearitas, uji heteroskedastisitas dan uji autokorelasi.

\subsubsection{Uji Normalitas Data}

Menurut Ghazali (2017:145) uji normalitas bertujuan untuk menguji apakah dalam model regresi variabel pengganggu arau residual mempunyai distribusi normal. 


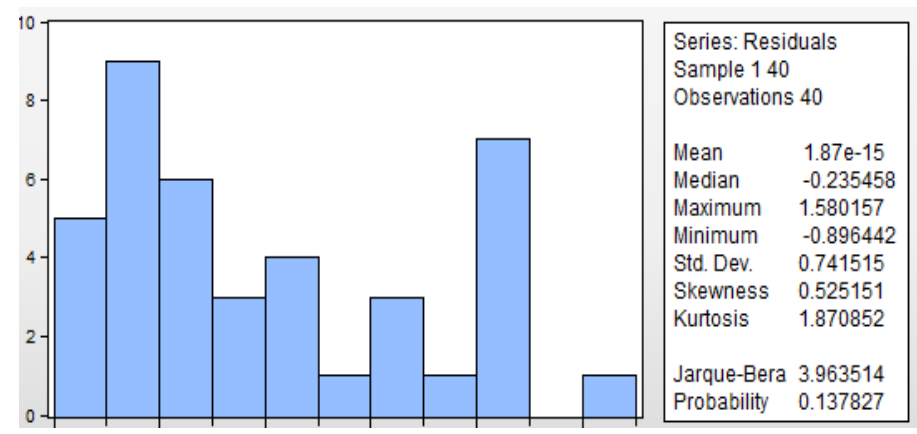

Gambar 2 : Uji Normalitas

Sumber : Data diolah

Berdasarkan tabel tersebut dapat diketahui bahwa nilai probilitas sebesar $0,137827>0,05$ maka dapat disimpulkan bahwa model regresi dalam penelitian ini berdistribusi dengan normal.

\section{Uji Multikolonieritas}

Menurut Ghozali (2017:71) uji multikolinearitas bertujuan untuk menguji apakah dalam model regresi ditemukan adanya korelasi yang tinggi atau sempurna antara variabel independen. Model yang baik seharusnya tidak terjadi korelasi yang tingi diantara variabel bebas.

Tabel 10 : Uji Multikolonieritas

\begin{tabular}{ccccc}
\hline & KI & KM & SG & Size \\
\hline KI & 1.000 & -0.563 & -0.143 & 0.015 \\
KM & -0.563 & 1.000 & 0.258 & -0.692 \\
SG & -0.143 & 0.258 & 1.000 & -0.235 \\
Size & 0.015 & -0.69 & -0.235 & 1.000 \\
\hline \multicolumn{5}{c}{ Sumber Data diolah }
\end{tabular}

Sumber : Data diolah

Berdasarkan tabel tersebut dapat diketahui bahwa nilai koefisien korelasi semua variabel independen dibawah 0,9 maka dapat disimpulkan bahwa tidak terjadi masalah multikolinearitas antar variabel independen dalam model regresi.

\section{Uji Heteroskedastisitas}

Menurut Ghazali (2017:87) uji heteroskedastisitas bertujuan untuk mengetahui apakah dalam model regresi terdapat ketidaksamaan varians dari variabel pengganggu antara pengamatan

Tabel 11 : Uji Heteroskedastisitas dan Autokorelasi

\begin{tabular}{lll}
\hline & Obs \&R-Square & Prob. Chi-Square \\
\hline Heteroskedastisitas & 2.359364 & 0.6700 \\
Autokorelasi & 0.312620 & 0.8553 \\
\hline
\end{tabular}

satu ke pengamatan lain. Model regresi yang baik adalah model regresi yang tidak terdapat heteroskedastisitas. Sementara itu, Menurut Ghazali (2017:121) uji autokorelasi bertujuan untuk menguji apakah dalam suatu model regresi linear ada korelasi anatarkesalahaan pengganggu (residual) pada periode $t$ dengan kesalahaan periode t-1 (sebelumnya). Pendekatan pada penelitian ini menggunakan uji white. 
Sumber : Data diolah

Berdasarkan tabel tersebut, untuk uji heteroskedastisitas dapat diketahui bahwa nilai $O b s^{*} R$-squared mempunyai nilai probablitas Chi-squared yaitu sebesar 0,6700>0,05. Dengan demikian maka dapat disimpulkan bahwa dalam model tidak terdapat heteroskedastisitas, sehingga memenuhi pesyaratan dalam analisis regresi. Sedangkan untuk uji autokorelasi diketahui bahwa nilai Obs*R-squared mempunyai nilai probabilitas Chisquare sebesar 0,8553>0,05. Dengan demikian dapat disimpulkan bahwa tidak terjadi masalah autokorelasi

\section{Uji Regresi Linear Berganda}

Tabel 12 : Uji Regresi Linear Berganda

\begin{tabular}{cccc}
\hline Keterangan & Koefisien & T statistic & Prob \\
\hline C & 6.98 & 1.244 & 0.22 \\
KM & 21.99 & 2.405 & 0.02 \\
KI & 0.091 & 0.410 & 0.68 \\
SG & -0.663 & -2.355 & 0.02 \\
Size & -0.237 & -1.260 & 0.21 \\
\hline
\end{tabular}

Sumber : Data diolah

\section{E, Pengujian Hipotesis}

Menurut Ghozali (2016:97) uji t digunakan untuk menguji hipotesis secara parsial guna menunjukkan seberapa jauh pengaruh satu variabel independen secara individual dalam menerangkan variabel dependen. Tabel menunjukkan $\mathrm{t}$ hitung untuk setiap variabel.

\section{Pengaruh Kepemilikan Manajerial terhadap Kebijakan Utang}

Kriteria pengujian hipotesis diterima jika prob $<0,05$. Berdasarkan tabel 15, nilai probabilitas variabel kepemilikan manajerial sebesar $0,0230<0,05$ dengan arah koefisien positif, maka dapat disimpulkan bahwa hipotesis deterima. Hal ini berarti bahwa kepemilikan manajerial berpengaruh positif secara signifikan terhadap kebijakan utang perusahaan sub sektor otomotif dan komponen.
Koefisien regresi kepemilikan manajerial $\left(X_{1}\right)$ 21,99199 menunjukkan bahwa jika kepemilikan manajerial meningkat sebesar satu satuan dan variabel lainnya konstan, maka kebijakan utang pada perusahaan sub sektor otomotif dan komponen akan meningkat sebesar 21,99199

\section{Pengaruh Kepemilikan Institusional terhadap Kebijakan Utang}

Kriteria pengujian hipotesis diterima jika prob $<0,05$. Berdasarkan tabel 15 , nilai probablilitas variabel kepemilikan institusional sebesar $0,6847>0,05$ dengan arah koefisien positif, maka dapat disimpulkan bahwa hipotesis ditolak. Dengan kata lain, artinya tidak terdapat pengaruh secara signifikan kepemilikan institusional terhadap kebijakan utang.

Koefisien regresi kepemilikan institusional $\quad\left(\mathrm{X}_{2}\right) \quad 0,917523$ menunjukkan bahwa jika institusional meningkat sebesar satu satuan dan 
variabel lainnya konstan, maka kebijakan utang pada perusahaan sub sektor otomotif dan komponen akan meningkat sebesar 0,917523.

Penelitian ini tidak sejalan dengan penelitian yang dilakukan oleh Indahningrum dan Handayani (2009), Larasati (2011), Nuraina (2012). Namun hasil penelitian ini mendukung penelitian yang dilakukan oleh Haruman (2008), Asuti (2014), Purwasih dkk. (2014) dan Gommohammadi, et all (2015).

Kepemilikan institusional yang cukup tinggi pada perusahaan sub sektor otomotif dan komponen hanya berkonsentasi pada penanaman modal. Kepemilikan institusional yang tinggi tidak mampu menjadi controller dan bukan berarti dapat ikut serta dalam proses pengambilan keputusan yang dilakukan oleh pihak manajemen perusahaan. Selain itu, sebagian investor tidak peduli dengan menggunaaan utang sebagai sumber dana perusahaan karena mereka lebih memperhatikan kinerja perusahaan yang baik.

\section{Pengaruh Pertumbuhan Penjualan terhadap Kebijakan Utang}

Kriteria pengujian hipotesis diterima jika prob $<0,05$. Berdasarkan tabel 15 , nilai probablilitas pertumbuhan penjualan sebesar $0,0257<005$ dengan arah koefisien negatif, maka dapat disimpulkan bahwa hipotesis diterima. Hal ini berarti bahwa secara parsial pertumbuhan penjualan berpengaruh negatif secara signifikan terhadap kebijakan utang.

Koefisien regresi pertumbuhan penjualan $\left(\mathrm{X}_{3}\right) \quad-\quad 0,663457$ menunjukkan bahwa jika pertumbuhan penjualan meningkat sebesar satu satuan dan variabel lainnya konstan, maka kebijakan utang pada perusahaan sub sektor otomotif dan komponen akan menurun sebesar - 0,663457.

Hasil penelitian ini sejalan dengan penelitian yang dilakukan oleh Bayunitri dan Malik (2015) yang menyatakan bahwa pertumbuhan penjualan berpengaruh negatif terhadap kebijakan utang. Namun hasil penelitian ini bertentangan dengan teori yang dikemukan Sudana (2011:162) yang menyatakan bahwa perusahaan yang tingkat pertumbuhan penjualannya relatif tinggi dimungkinkan untuk dibelanjai dengan menggunakan utang yang lebih besar dan perusahaan yang penjualannya relatif stabil dari waktu ke waktu dimungkinkan untuk dibelanjai dengan utang yang lebih banyak.

Ketika pertumbuhan penjualan mengalami peningkatan, maka laba yang diperoleh akan meningkat. Peningkatan laba akan berpengaruh pada sumber dana internal yang berlimpah. Berdasarkan pecking order theory, keputusan pendanaan perusahaan didasarkan pada urutan sumber pendanaan yaitu laba internal, utang dan penerbitan saham. Dalam teori ini perusahaan lebih mengutamakan pendanaan internal daripada pendanaan eksternal.

\section{Pengaruh Ukuran Perusahaan terhadap Kebijakan Utang}

Kriteria pengujian hipotesis diterima jika prob $<0,05$. Berdasarkan nilai probablilitas ukuran perusahaan sebesar 0,2179>0,05 dengan arah koefisien negatif, maka dapat disimpulkan bahwa hipotesis ditolak. Dengan kata lain, ukuran perusahaan tidak berpengaruh secara signifikan terhadap kebijakan utang.

Koefisien regresi ukuran perusahaan $\left(\mathrm{X}_{4}\right)-0,237230$ menunjukkan bahwa jika ukuran perusahaan meningkat sebesar satu satuan dan variabel lainnya 
konstan, maka kebijakan utang pada perusahaan sub sektor otomotif dan komponen akan menurun sebesar 0,237230 .

Hasil penelitian ini tidak sejalan dengan penelitian yang dilakukan oleh Astuti (2014), Hasan (2014), namun mendukung penelitian yang dilakukan oleh Steven dan Lina (2011), Nuraina (2012). Ukuran perusahaan bukanlah penentu sumber pendaanaan yang dipilih oleh perusahaan. Perusahaan besar ataupun kecil memiliki utang yang tidak selalu dipengaruhi oleh ukuran perusahaan. Sehingga ukuran perusahaan tidak berpengaruh terhadap kebijakan utang secara langsung.

\section{Uji F}

Menurut Ghozali (2016:95) uji F merupakan pengujian hubungan regresi secara simultan untuk mengetahui apakah semua variabel bebas mempunyai pengaruh secara simultan terhadap variabel dependen.

Tabel 13: Uji F

\begin{tabular}{ccc}
\hline F-Statistic & Prob & F Tabel \\
\hline 70.290 & 0.0000 & 3.94 \\
\hline \multicolumn{3}{c}{ Sumber : Data diolah }
\end{tabular}

Berdasarkan tabel tersebut, dapat diketahui $F_{\text {hitung }}$ 70,29091 lebih besar dari $\mathrm{F}_{\text {tabel }} 3,94$. Hal ini berarti bahwa kepemilikan manajerial, kepemilikan institusional, pertumbuhan penjualan dan ukuran perusahaan secara simultan memiliki pengaruh terhadap kebijakan utang pada perusahaan sub sektor otomotif dan komponen.

\section{SIMPULAN}

Persentase kepemilikan manajerial maksimum sebesar 12,40 \% dimilki oleh NIPS sedangkan persentase kepemilikan manajerial minimum sebesar $0 \%$ dimiliki oleh IMAS dan AUTO. Persentase kepemilikan institusional maksimum sebesar 89,66\% dimiliki oleh IMAS dan minimum sebesar $37,11 \%$ dimiliki oleh ASII . Persentase pertumbuhan penjualan maksimum sebesar 40,96\% dimiliki oleh PRAS dan minimum sebesar 21,92\% dimiliki oleh PRAS. Ukuran perusahaan maksimum sebesar 33,32 dimiliki oleh ASII dan minimum sebesar 27,40 dimiliki oleh PRAS. DER maksimum sebesar 2,82 dimiliki oleh IMAS minimum sebesar 0,14 dimiliki oleh INDS.

Secara parsial, kepemilikan manajerial berpengaruh positif secara signifikan terhadap kebijakan utang. Kepemilikan institusional tidak berpengaruh secara signifikan terhadap kebijakan utang. Pertumbuhan penjualan berpengaruh negatif secara signifikan terhadap kebijakan utang. Ukuran perusahaan tidak berpengaruh secara signifikan terhadap kebijakan utang. Kepemilikan manajerial, kepemilikan institusional, pertumbuhan penjualan dan ukuran perusahaan secara simultan memiliki pengaruh terhadap kebijakan utang perusahaan sub sektor otomotif dan komponen.

Penelitian ini masih banyak kekurangan, terutama terkait dengan jumlah tahun yang digunakan. Penelitian selanjutnya diharapkan dapat menganalisis kebijakan utang dari faktor atau variabel lainnya dan sektorsektor lainnya.1

\section{DAFTAR PUSTAKA}

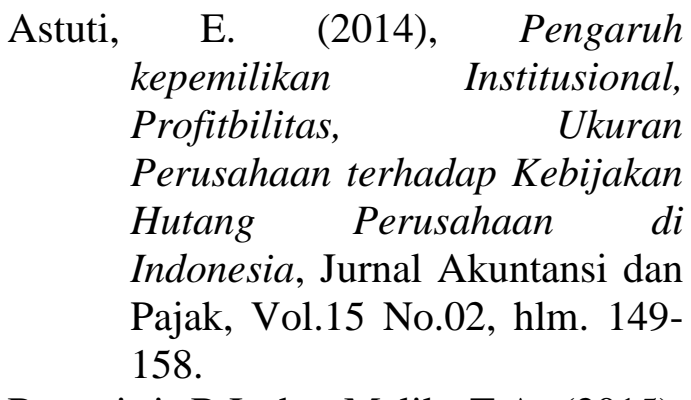

Bayunitri, B.I. dan Malik, T.A. (2015), Analisis Faktor-faktor yang 
Mempengaruhi Struktur Modal pada Perusahaan Manufaktur, Study and Accounting Research, Vol.XII No.1, hlm. 49-58.

Brigham, E.F. dan Houston, J.F. (2009), Dasar-dasar Manajemen Keuangan, Edisi 10, Jakarta: Salemba Empat.

Brigham, E.F. dan Houston, J.F. (2011), Dasar-dasar Manajemen Keuangan, Edisi 11, Buku 1, Jakarta: Salemba Empat.

Golmohammadi, J. dan Jafari M. (2015), The Effects of Return on Investment, Sales Growth Rate, Volatility of Investment, Cash Flow and Structure of Institutional Shareholders on The Ratio of Debt to Equities, Management Science Letters 5, hlm. 1042-1046.

Ghozali, I. (2016), Aplikasi Analisis Multivariete dengan Program IBM SPSS 23, Edisi 8, cetakan ke-8. Semarang : Badan Penerbit Universitas Diponegoro.

Ghazali, I. dan Ratmono, D. (2017), Analisis Multivariat dan Ekonometrika (Teori, konsep, dan Aplikasi dengan EViews 10), Edisi Kedua, Yogyakarta: Badan Penerbit Universitas Dipenegoro.

Harahap, S.S. (2015), Analisis Kritis atas Laporan Keuangan, Edisi Pertama cetakan ke duabelas, Jakarta: PT Raja Grafindo Persada.

Haruman, T. (2008), Pengaruh Struktur Kepemilikan Terhadap Keputusan Pendanaan (Perspektif Agency Theory) Survey pada Perusahaan Manufaktur di PT Bursa Efek Indonesia, National Conference on Management Research.

Hasan, M.A. (2014), Pengaruh Kepemilikan Manajerial, Free
Cash Flow dan Ukuran Perusahaan Terhadap Kebijakan Utang (Studi Pada Perusahaan-perusahaan

Industri Dasar dan Kimia yang Terdaftar di BEI), Jurnal Akuntansi, Vol. 3 No. 1, hlm. 90 -100 .

Hidayat, M.S. (2013), Pengaruh Kepemilikan Manajerial, Kebijakan Dividen, Struktur Aktiva, Pertumbuhan Penjualan dan Ukuran Perusahaan terhadap Kebijakan Utang, Jurnal Ilmu Manajemen, Vol.1 No.1, hlm. 12-25.

Hery. (2017), Kajian Riset Akuntansi (Mengulas Berbagai Hasil Penelitian Terkini dalam Bidang Akuntansi dan Keuangan), Jakarta: PT Grasindo.

http://www.idx.co.id, diunduh 18 Sepetember 2018.

http://www.kontan.co.id, diunduh 24 September 2018.

http://www.sahamok.com, diunduh 15 September 2018.

Indahningrum, R.P. dan Handayani, R. (2009), Pengaruh Kepemilikan Manajerial, Kepemilikan Institusional, Dividen, Pertumbuhan Perusahaan, Free Cash Flow dan Profitabilitas Terhadap Kebijakan Hutang Perusahaan, Jurnal Bisnis dan Akuntansi, Vol.11 No.3, hlm. 189-207.

Kahar, S.H.A. (2008), Kepemilikan Manajerial Terhadap Keputusan Pendanaan dan Dividen, Jurnal Keuangan dan Perbankan, Vol.12 No.3, hlm. 399 - 410.

Kasmir. (2013), Analisis Laporan Keuangan, Edisi Pertama, cetakan ke-6, Jakarta: Rajawali Pers.

Larasati, E. (2011), Pengaruh Kepemilikan Manajerial, 
Kepemilikan Institusional dan Kebijakan Dividen terhadap Kebijakan Hutang Perusahaan, Jurnal Ekonomi Bisnis, TH.16 No.2, hlm. 103-107.

Mulyati, Y. (2016), Pengaruh Struktur Asset dan Pertumbuhan Penjualan Terhadap Kebijakan Utang, Prodi Manajemen Fakultas Ekonomi dan Bisnis Universitas Jember, hlm. 813831.

Musthafa. (2017), Manajemen Keuangan, Edisi Pertama, Yogyakarta: CV Andi Offset.

Nuraina, E. (2012), Pengaruh Kepemilikan Institusional dan Ukuran Perusahan Terhadap Kebijakan Hutang dan Nilai Perusahaan (Studi pada Perusahaan Mannufaktur yang Terdaftar di BEI, Jurnal Akuntansi, Vol.4 No.1, hlm. 5170.

Purwasih,D. Agusti,R. dan Azhar, A. (2014), Analisis Pengaruh Kepemilikan Manajerial, Kepemilikan Institusional, Kebijakan Dividen, Profitabilitas, Ukuran Perusahaan dan Struktur Aset terhadap Kebijakan Hutang pada Perusahaan Manufaktur yang Terdaftar di Bursa Efek Indonesia periode 2010-2012, JOM FEKON, Vol.1 No.2, hlm. 1-12.

Soukotta, A. (2012), Analisis Faktorfaktor yang Mempengaruhi Sruktur Modal (Studi Perbandingan pada Manufacture Multinational Company dan Manufacture Domestic Corporation di Bursa Efek Indonesia, Vol.21 No.1, hlm.1-17.

Steven dan Lina. (2011), Faktor-faktor yang Mempengaruhi Kebijakan Hutang
Manufaktur, Jurnal Bisnis dan Akuntansi, Jurnal Bisnis dan Akuntansi, Vol.13 No.3, hlm. 163-181.

Subagyo., Masruroh, N.A. dan Bastian, I. (2017), Akuntansi Manajemen Berbasis Desain, Yogyakarta: Gadjah Mada University Press.

Sudana, I.M. (2011), Manajemen Keuangan Peusahaan (Teori dan Praktik), Jakarta: Erlangga.

Sudana, I.M. (2015), Manajemen Keuangan Peusahaan (Teori dan Praktik), Edisi Kedua, Jakarta: Erlangga.

Sugiyono. (2014), Metode Penelitian Kuantitatif, Kualitatif, dan $R \& D$. Bandung: Alfabeta.

Wahyudi, T S. (2016), Konsep dan Penerapan Ekonometrika Menggunakan E-views, Edisi Pertama, Jakarta : Rajawali Pers.

Widarjono, A. (2016), Ekonometrika Pengantar dan Aplikasinya Disertai Pandua E-views, Edisi Keempat, cetakan ke-2, Yogyakarta : UUP STIM YKPN. 